\title{
The Iron Content of Serum Ferritin: Physiological Importance and Diagnostic Value
}

\author{
Joop ten Kate ${ }^{1}$, Albert Wolthuis ${ }^{1}$, Bert Westerhuis ${ }^{1}$ and Cees van Deursen ${ }^{2}$ \\ ${ }^{1}$ Department of Clinical Chemistry \\ 2 Department of Internal Medicine \\ De Wever and Gregorius Hospital, Heerlen, Brunssum, The Netherlands
}

\begin{abstract}
Summary: In this paper we present a method for determining the iron saturation of ferritin as a possible independent predictor of iron stores. Serum ferritin was purified by immunochemical precipitation, and could be completely recovered from serum without any contamination from transferrin. The iron content of the precipitated ferritin was determined by flameless atomic absorption spectrophotometry (FAAS) and the ferritin-iron saturation was calculated using the original serum ferritin concentration. The intra- and inter-assay variation coefficients were $4.2 \%$ and $13.4 \%$ respectively.

The first results with this assay indicate that serum ferritin contains a considerable amount of iron. Furthermore the results show that the iron saturation of ferritin in patients with acute phase response is significantly lower than the saturation found in healthy volunteers $(19.3 \%$ and $24.3 \%$ respectively). These results suggest a possible role for the ferritin-iron saturation in the assessment of iron stores in patients suffering from acute phase response. In addition, the considerable amount of iron in ferritin suggests the need to revise the physiological role of this substance in relation to the serum iron homeostasis.
\end{abstract}

\section{Introduction}

For the determination of the iron status in anaemic patients several indicators can be used, such as serum iron, transferrin, transferrin iron binding capacity and ferritin. Ferritin is the method of choice to estimate the iron stores. It has been proposed that circulating ferritin may act as a transport protein for iron between the reticuloendothelial cells and the erythron, but the reported low iron contents of serum ferritin, even in iron overload states, makes this unlikely $(1,2)$. Several authors demonstrated the existence of ferritin receptors on the surface of erythrons and macrophages, however the function of these receptors is still unknown (3-4). With this in mind we were interested in the iron content of serum ferritin.

Ferritin acts as a positive acute phase reactant. Therefore, especially in chronic disease, the measurement of ferritin is not a reliable analyte for assessing the iron stores. Iron deficiency can be obscured by high ferritin concentrations due to the acute-phase response. The ferritin level in serum may also be increased due to liver cell damage or to malignancies. Witte et al. $(6,7)$ suggested that ferritin concentrations, if corrected for the acute phase response, could still be used to estimate the iron stores in bone marrow, even in patients with chronic disease. The applied nomograms describing the relation between ferritin concentration and C-reactive protein or erythrocyte sedimentation rate values, in order to diagnose or exclude iron deficiency anaemia in patients with chronic disease. This was done in an effort to minimize the numbers of bone marrow examination needed. In our institute the data of Witte et al. $(6,7)$, were not confirmed by Coenen et al. (8).

Recently, new efforts were undertaken to tackle this problem. A working hypothesis was formulated: In the case of inflammation and iron deficiency anaemia, the iron content of the increased level of ferritin is low.

To test this hypothesis a simple method had to be developed in order to determine the iron content of serum ferritin.

This paper deals with the description of this technique and gives the first results obtained with this method. During the European Iron Club meeting in Hamburg in September last year, part of these results were presented (9).

\section{Materials and Methods}

Flameless atomic absorption measurements were performed on a Perkin Elmer (Überlingen, Germany) model 3030 spectrophotometer with deuterium background correction, equipped with a PE HGA500 graphite furnace atomizer (programmable) and a PE AG40 autosampler. The iron hollow cathode lamp was from Instrumentation Laboratories (Palermo, Italy) no. 89225. Instrumental conditions are summarized in table 1 . 
Tab. 1 Instrumental conditions for the determination of iron by flameless atomic absorption spectrophotometry

Sample volume $20 \mu \mathrm{l}$

Fe hollow cathode lamp $30 \mathrm{~mA}$

Slit width $0.2 \mathrm{~nm}$, alternate

Wavelength $248.3 \mathrm{~nm}$

Deuterium background detector on graphite furnace tube with $L$ 'vov platform, pyrolytic coated

Purge gas, argon: $330 \mathrm{ml} / \mathrm{min}$

Calibration auto select

Iron standards $0,25,50$, and $100 \mu \mathrm{g} / 1$

\begin{tabular}{|c|c|c|c|}
\hline Dry cycle & $\begin{array}{l}130^{\circ} \mathrm{C} \\
250^{\circ} \mathrm{C}\end{array}$ & $\begin{array}{l}10 \mathrm{~s} \text { ramp } \\
10 \mathrm{~s} \text { ramp }\end{array}$ & $\begin{array}{r}20 \mathrm{~s} \text { hold } \\
5 \mathrm{~s} \text { hold }\end{array}$ \\
\hline Char cycle & $\begin{array}{r}850^{\circ} \mathrm{C} \\
1400^{\circ} \mathrm{C} \\
1400^{\circ} \mathrm{C}\end{array}$ & $\begin{array}{l}5 \mathrm{~s} \text { ramp } \\
5 \mathrm{~s} \text { ramp } \\
1 \mathrm{~s} \text { ramp }\end{array}$ & $\begin{array}{l}5 \mathrm{~s} \text { hold } \\
5 \mathrm{~s} \text { hold } \\
5 \mathrm{~s}^{1} \text { hold }^{1}\end{array}$ \\
\hline Atomize & $2400^{\circ} \mathrm{C}$ & $0 \mathrm{~s}$ ramp & $5 \mathrm{~s} \mathrm{hold}^{12}$ \\
\hline Clean & $2700^{\circ} \mathrm{C}$ & $1 \mathrm{~s} \mathrm{ramp}$ & $3 \mathrm{~s}$ hold \\
\hline Cool & $20^{\circ} \mathrm{C}$ & $1 \mathrm{~s} \mathrm{ramp}$ & $20 \mathrm{~s}$ hold \\
\hline
\end{tabular}

${ }^{1}$ Gas flow interrupt

2 Signal processing, peak area, $5 \mathrm{~s}$ after start atomizer cycle Calibration mixtures were prepared from a ferric nitrate standard solution $1 \mathrm{~g} / \mathrm{l}$, Spectrosol, BDH Chemicals) in $200 \mathrm{mmol} / 1 \mathrm{nitric}$ acid.

The ferritin assay was performed on the Stratus fluorometric analyzer using the Stratus ferritin fluorometric enzyme immunoassaykit (B5700-56, Baxter Diagnostics Inc., Deerfield, IL, USA) according to the manufacturers protocol.

Beads coated with anti-ferritin antibodies were from Biorad (Quantimmune ${ }^{\circledR}$-Ferritin-IRMA, Biorad, Clinical Division, Hercules, CA, USA). Before use the beads were washed in Sørensen buffer, in order to remove the radioactively labelled antibodies, and stored at $4{ }^{\circ} \mathrm{C}$.

The iron content of ferritin is determined as follows: $300 \mu \mathrm{l}$ serum (with known ferritin concentration, not more than $1000 \mu \mathrm{g} / \mathrm{l}$ ) are combined with an overestimate of $300 \mu 1$ beads in an iron-free glass tube, and incubated for 30 minutes. The beads are separated from the supernatant by centrifugation ( 10 minutes at $\left.3000 \mathrm{~min}^{-1}\right)$. Subsequently the beads are washed three times with $300 \mu \mathrm{l} 9 \mathrm{~g} / \mathrm{l}$ saline at $4{ }^{\circ} \mathrm{C}$. Bidistilled water $(300 \mu \mathrm{l})$ is added to the beads followed by an incubation of 60 minutes at $90^{\circ} \mathrm{C}$ in a water-bath. After a 10 minute centrifugation $\left(3000 \mathrm{~min}^{-1}\right)$ the iron content of the supernatant is determined with flameless AAS.

An experiment was performed to establish the washing procedure and the results are shown in table 2 . From these results it can be concluded that after three washings most of the serum iron is removed and that the losses of ferritin and iron are acceptable.

\section{Calculation of the ferritin iron saturation}

The relative molecular mass of ferritin is 450000 , while the total number of iron molecules per molecule ferritin is reported to be around 4500 (1). The maximal amount of iron is taken as $100 \%$. Thus, a ferritin concentration of $\mathrm{x} \mu \mathrm{g} / \mathrm{l}$ and an iron concentration in the ferritin of $y \mu g / l$, gives a saturation percentage $(\mathrm{z} \%)$ of:

$$
[(\mathrm{y} / 55.8) /\{(\mathrm{x} / 450000) \times 4500\}] \times 100 \%=\mathrm{z} \%
$$

\section{Results}

\section{Ferritin isolation from serum}

In figure 1 the results are shown from an experiment in which a serum sample was incubated with beads coated with anti-ferritin antibodies. Ferritin removal from the serum is $100 \%$, while the transferrin concentration is unaffected. The isolated ferritin is removed from the beads by heating at $90{ }^{\circ} \mathrm{C} 60$ minutes; to estimate the iron content of the ferritin the iron content of the supernatant is determined by FAAS. In order to estimate whether all iron was removed from the beads, an experiment was performed in which the denaturation procedure with the ferritin coated beads with diluted $(0.24 \mathrm{~mol} / \mathrm{l}) \mathrm{HNO}_{3}$ was compared to the aqua dest. denaturation. Denaturation of the beads with $\mathrm{HNO}_{3}$ did result in iron concentrations of the supernatant comparable to the denaturation with aqua dest., indicating that the removal of the iron is complete (data not shown). The ferritin content of the beads equals the content of the original serum sample because of the $100 \%$ removal of the ferritin from the serum (fig. 1). The intra- and inter-assay coefficients of variation of the new technique, described in this paper, were found to be satisfactory $(4.2 \%$ and $13.4 \%$ respectively; tab. 3).

Tab. 2 Representative experiment of iron measurement in ferritin, in which the ferritin and iron losses during the several washing procedures are measured.

\begin{tabular}{|c|c|c|c|c|}
\hline \multirow[t]{2}{*}{$\begin{array}{l}\text { Wash- } \\
\text { ings }\end{array}$} & \multirow{2}{*}{$\begin{array}{l}\text { Ferritin } \\
\text { concentration } \\
\text { in washing } \\
\text { solutions } \\
(\mu \mathrm{g} / 1)\end{array}$} & \multicolumn{2}{|c|}{$\begin{array}{l}\text { Iron } \\
\text { concentration } \\
\text { in washing } \\
\text { solutions }\end{array}$} & \multirow{2}{*}{$\begin{array}{l}\text { Iron } \\
\text { concentration } \\
\text { in solution after } \\
\text { denaturation } \\
(\mu \mathrm{g} / \mathrm{l})\end{array}$} \\
\hline & & $(\mu \mathrm{g} / 1)$ & $(\%)$ & \\
\hline $0^{*}$ & 0.9 & 550 & 100 & 75 \\
\hline 1 & 3.3 & 182 & 33 & 59 \\
\hline 2 & 7.5 & 61 & 11 & 52 \\
\hline 3 & 3.3 & 17 & 3 & 51 \\
\hline 4 & 2.8 & 9 & 2 & 56 \\
\hline 5 & 2.3 & 5 & 1 & 48 \\
\hline
\end{tabular}

* Serum

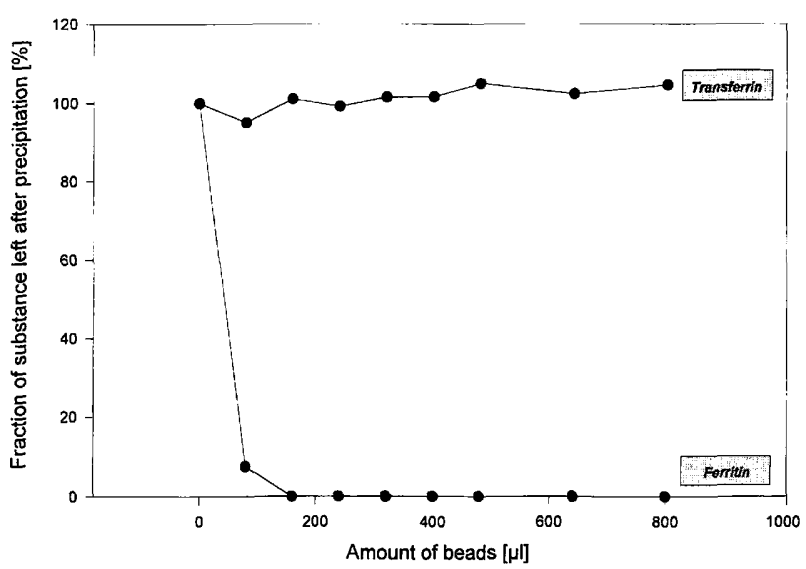

Fig. 1 Transferrin and ferritin concentration as a percentage of the initial value in a serum sample incubated with increasing amounts of anti-ferritin antibody coated beads. 
Tab. 3 Intra- and inter-assay coefficients of variation of the iron content in ferritin.

\begin{tabular}{|c|c|}
\hline $\begin{array}{l}\text { Intra-assay } \mathrm{CV}^{1} \\
4.2 \%\end{array}$ & $\begin{array}{l}\text { Inter-assay } \mathrm{CV}^{2} \\
13.4 \%\end{array}$ \\
\hline Mean iron value: $108 \mu \mathrm{g} / 1$ & Mean iron value: $101 \mu \mathrm{g} / \mathrm{l}$ \\
\hline SD: $\quad 4.6 \mu \mathrm{g} / 1$ & $12.0 \mu \mathrm{g} / \mathrm{l}$ \\
\hline
\end{tabular}

${ }^{1}$ In one series of measurements the same sample was determined 10 times.

${ }^{2}$ On 10 consecutive days the same sample was measured once a day.

\section{Linearity of the assay}

The linearity of the assay was estimated by stepwise dilution (with saline) of a sample from a known haemochromatosis patient. The results are shown in figure 2. The linearity was acceptable until the $\mathrm{Fe}$ concentration dropped below $10 \mu \mathrm{g} / \mathrm{l}$. So at a saturation of $20 \%$, the detection limit of this ferritin assay was found to be $100 \mu \mathrm{g} / 1$. In order to exclude matrix effects a serum sample with a very low ferritin concentration was used as a diluent, the results were comparable (data not shown).

\section{Preliminary patient data}

The ferritin iron saturation in the serum of 10 healthy male volunteers was measured. The iron saturation of ferritin was also determined in a group of 47 patients selected on the basis of a high erythrocyte sedimentation rate. Table 4 shows the comparison between healthy volunteers and patients with an acute phase reaction. From the range it can be seen that the iron ferritin saturation percentages vary from 5 to $50 \%$, so the amount of iron in ferritin is considerable. Furthermore these data suggest that in patients with an acute phase reaction the iron saturation of ferritin is statistically significantly $(p<0.05)$ lower than in healthy controls.

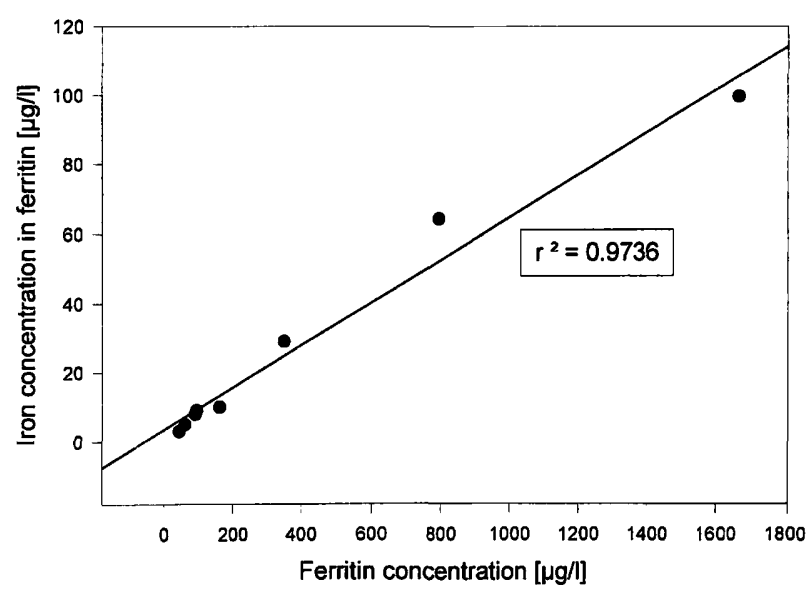

Fig. 2 Linearity of the assay. Each point is measured in triplicate.

\section{Discussion}

The iron saturation of ferritin was found to be rather high, up to $50 \%$. A ferritin concentration of $200 \mu \mathrm{g} / 1$ with an iron content of $40 \%$ contributes around $6 \%$ to the total serum iron concentration. The biological role of this considerable amount of circulating iron store still has to be elucidated. However, a dynamic role for serum ferritin with respect to iron transport is not unlikely since the presence of ferritin receptors on lymphoid and erythroid cells has been known for many years (3-5, $10,11)$. In addition Meyron-Holtz et al. (4) recently reported that ferritin bound to its receptor is internalized and may be important as a donor of iron in erythroid cells.

Earlier investigations describe lower saturation percentages of ferritin, $2.5-11 \%$ molar percentages $(12-15)$. The method presented in this paper is much more direct than the methods which were applied by earlier investigators. They may have lost iron from the ferritin during laborious and time consuming-chromatographic isolation procedures, using elution buffers without iron. Herbert et al. (16) recently published an abstract in which they reported iron saturation percentages of $11-50 \%$, which is in line with our results.

With the technique presented here it will be possible to study the ferritin iron saturation in various pathological conditions, such as patients with anaemia and chronic disease. The preliminary data obtained with patients having acute phase response are in line with our working hypothesis that the iron saturation of ferritin is lower in these patients. The results described in this paper are supported by the work of Herbert et al. (16), who stated in their abstract that inflammation is characterized by an increased number of ferritin molecules each containing a "subnormal" quantity of iron.

Ferritin molecules are composed of 24 subunits. A common structure of most ferritin protein molecules is the composition of different ratios of the primary ferritin subunit chains: the $\mathrm{L}$ (light) subunit $M_{\mathrm{r}} 19500$ and the $\mathrm{H}$ (heavy) subunit $M_{\mathrm{r}} 21000$ (17). It is known that ferritin synthesis under influence of acute phase cytokines such

Tab. 4 Iron saturation of ferritin in 47 patients having an acute phase reaction, compared to 10 healthy volunteers.

\begin{tabular}{lll}
\hline & $\begin{array}{l}\text { Healthy } \\
\text { volunteers } \\
(\mathrm{n}=10)\end{array}$ & $\begin{array}{l}\text { Patients with } \\
\text { acute phase } \\
(\mathrm{n}=47)\end{array}$ \\
\hline $\begin{array}{l}\text { Ferritin concentration } \\
(\mu \mathrm{g} / \mathrm{l}) \text { mean (SD) }\end{array}$ & $111.8(81.6)$ & $445.2(56.6)$ \\
$\begin{array}{l}\text { Iron saturation of ferritin } \\
(\%) \text { mean (SD) } \\
\text { (range) }\end{array}$ & $\begin{array}{l}24.3(8.2)^{*} \\
(11-37)\end{array}$ & $\begin{array}{l}19.3(7.4)^{*} \\
(5-42)\end{array}$ \\
\hline
\end{tabular}

* significant difference $\mathrm{p}<0.05$ (Students $\mathrm{t}$ test) 
as the interleukins (IL) IL-1 $\beta$, IL-6 and tumour necrosis factor- $\alpha$ (TNF- $\alpha$ ) is more in favour of the $H$ subunit, while under influence of iron both subunits are up-regulated (18). If such a shift is considered during the acute response in our group of patients, theoretically a maximum shift would result in $M_{\mathrm{r}}$ of 504000 (24 H subunits). This means an increase in $M_{\mathrm{r}}$ of $8 \%$, which results in an increase of the calculated iron saturation of ferritin of $8 \%$. This may compensate for the observed decrease of iron-saturation of ferritin of $5 \%$ (tab. 4) in this group of patients, although such a dramatic shift in isoforms is unlikely. Glycosylation could have been another disturbing factor, since it is known that serum ferritin is also composed of a glycosylated subunit $\left(M_{\mathrm{r}} 23000\right)$. However we do not have to take this into account because the serum ferritin and liver- and spleen ferritin, in the applied assay, react in the same way (manufacturers' information). This indicates that the epitopes used in this assay are unaffected by glycosylation.

The group of patients which were investigated was very heterogenous with respect to the cause of the acute phase response. Further investigation on patients with

\section{References}

1. Haliday JW, Powell LW. Ferritin metabolism and the liver. Semin Liver Dis 1984; 4:207-16.

2. Cavill I, Jacobs A, Worwood M. Diagnostic methods for iron status. Ann Clin Biochem 1986; 23:168-71.

3. Aisen P. Ferritin receptors and the role of ferritin in iron transport. Targeted Diagn Ther 1991; 4:339-54.

4. Meyron-Holtz EG, Fibach E, Gelvan D, Konijn AM. Binding and uptake of exogenous isoferritins by cultured human erythroid precursor cells. Br J Haematol 1994; 86:635-41.

5. Morikawa K, Oseko F, Morikawa S. A role for ferritin in haematopoiesis and the immune system. Leuk Lymphoma $1995 ; 18: 429-33$.

6. Witte DL, Angstadt DS, Davis SH, Schrantz RD. Predicting bone marrow iron stores in anemic patients in a community hospital using ferritin and erythrocyte sedimentation rate. Am J Clin Pathol 1988; 90:85-7.

7. Witte DL, Kraemer DF, Johnson GF, Dick FR, Hamilton H. Prediction of bone marrow iron findings from tests performed on peripheral blood. Am J Clin Pathol 1986; 85:202-6.

8. Coenen JLIM, Dieijen-Visser MP van, Pelt J van, Deursen CTBM van, Fickers MMF, Wersch JWJ van, Brombacher PJ. Measurement of serum ferritin used to predict concentrations of iron in bone marrow in anemia of chronic disease. Clin Chem 1991; 37:560-3.

9. Westerhuis L, Kate J ten, Wolthuis A, Deursen C van. Determination of the iron content of serum ferritin. Clin Lab Haematol $1995 ; 7: 380-1$.

10. Broxmeyer HE, Bognacky J, Ralph P, Dorner MH, Lu LI, Castro-Malaspina H. Monocyte-macrophage-derived acidic isoferritins: normal feedback regulators of granulocyte-macrophage progenitor cells in vitro. Blood 1982; 60:595-607.

11. Broxmeyer HE, Lu LI, Bicknell DC, Williams DE, Cooper S, Levi S, Salfield J, Arosio P. The influence of purified recombi- well-defined conditions causing an acute phase response, for instance rheumatoid arthritis, are necessary to prove the value of this method in clinical practice.

Instead of a bone marrow biopsy, the iron saturation of the ferritin may also be helpful in assessing the iron stores of patients with anaemia and chronic disease. At the moment this work is in progress in our institute. Furthermore the ferritin iron saturation is of interest when dealing with haemochromatosis patients with respect to the monitoring of therapy. Further insight into the kinetics of iron transport and storage processes may help in the diagnosis and follow-up of iron deficiency, while the role of ferritin as a transporter of iron has to be reconsidered.

\section{Acknowledgements}

We would like to thank Yvonne Ramakers-Baur, Wiel Visschers and Meriam Kuipers for skillfull technical assistance, Prof. dr. J. J. M. Marx for providing us with the serum of a haemochromatosis patient and for helpful discussions, and Biorad for providing the ferritin coated beads. This study was supported by the Van de Laar Stichting.

nant human heavy-subunit ferritins on colony formation in vitro by granulocyte-macrophage and erythroid progenitor cells. Blood 1986; 68:1257-63.

12. Worwood M, Dawkins S, Wagstaff M, Jacobs A. The purification and properties of ferritin from human serum. Biochem J $1976 ; 157: 97-103$.

13. Arosio P, Yokata M, Drysdale JW. Characterization of serum ferritin in iron overload: possible identity to natural apoferritin. Br J Haematol 1977; 36:199-207.

14. Cragg SJ, Wagstaff M, Worwood M. Detection of a glycosylated subunit in human serum ferritin. Biochem J 1981; 199:565-71.

15. Pootrakul P, Josephson B, Huebers HA, Finch CA. Quantification of ferritin iron in plasma, an explanation for non-transferrin iron. Blood 1988; 71:1120-3.

16. Herbert V, Shaw S, Jayatilleke E. High serum ferritin protein does not distinguish iron overload from inflammation, but a new assay, high serum ferritin-iron, does. Am J Clin Nutr 1995; 61:911.

17. Arosio P, Adelman TG, Drysdale JW. On ferritin heterogeneity. Further evidence of heteropolymers. J Biol Chem 1978; 253:4451-8.

18. Konijn AM. Iron metabolism in inflammation. Balliere's Clin Haem Int Pract Res 1994; 7:829-51.

Received June 25/October 17, 1996

Corresponding author: Dr. Joop ten Kate, Department of Clinical Chemistry, De Wever and Gregorius Hospital, PO Box 4446, NL6401 CX Heerlen, The Netherlands 